\title{
90. The Enzymatic Degradation of Heme Proteins into Bile Pigments. IX
}

\author{
The Activator of Heme $\alpha$-Methenyl Oxygenase. I \\ Tsutomu TAKemura \\ First Department of Internal Medicine, Faculty of Medicine, \\ Kyushu University, Fukuoka \\ (Comm. by N. ONODERA, M.J.A., July 12, 1962)
}

In the previous communications, ${ }^{1-6)}$ it was demonstrated that the conversion of pyridine-hemichromogen by liver homogenate into the $656 \mathrm{~m} \mu$ substance, which was a direct precursor of biliverdin, was an enzymatic reaction. The enzyme catalyzing this process was termed "heme $\alpha$-methenyl oxygenase"." About 70 to $80 \%$ of the activity of the liver homogenate was shown to be distributed in the supernatant fraction using Schneider's method of differential centrifugation, ${ }^{8)}$ while the other fractions seemed to have a little or no enzyme activity. ${ }^{4}$ Recently, it was discovered that the activity of the supernatant fraction was markedly increased by preincubation with the nuclear fraction. These facts indicate that there exists a certain factor in the nuclear fraction, which is effective in the activation of the enzyme activity.

This paper describes the fact that the increment of the enzyme activity of the supernatant fraction by preincubation with the nuclear fraction was due to the release of the activator from the nuclear fraction.

Experimental Procedure. Preparation of Enzyme. The particulate free supernatant was obtained by the centrifugation of the guinea pig liver homogenate at $105,000 \mathrm{xg}$ for 60 minutes and was used as the enzyme preparation. The detailed procedures for the preparation were described in the previous communication. ${ }^{9)}$

Preparation of Intracellular Particulate Fraction. The method used was essentially the same as described by Schneider, ${ }^{8)}$ and a $0.25 \mathrm{M}$ sucrose solution was used as the homogenization medium.

Preparation of Substrate, Boiled Liver Extract and Assay Method. These were essentially the same as described in the previous communication,9) excepting that the reaction mixture was incubated for 20 minutes. Protein was measured by the use of the spectrophotometric method of Warburg and Christian, ${ }^{10)}$ unless the special description was done.

Results and Discussions. About $75 \%$ of the enzyme activity of the homogenate were recovered in the supernatant fraction, while 
other fractions were almost without activity. The increase of the activity of supernatant due to the addition of other fractions did not exceed 10\% (Table I and II). The supernatant obtained by

Table I. The intracellular distribution of the enzyme activity

\begin{tabular}{l|c|c|c|c}
\hline \multicolumn{1}{c|}{ Fraction } & $\begin{array}{c}\text { Activity } \\
\text { (units/ml) }\end{array}$ & $\begin{array}{c}\text { Protein } \\
(\mathrm{mg} / \mathrm{ml})\end{array}$ & $\begin{array}{c}\text { Specific activity } \\
\text { (units/mg protein) }\end{array}$ & $\begin{array}{c}\text { Total activity } \\
\text { (units) }\end{array}$ \\
\hline Homogenate & 7.00 & 16.0 & 0.437 & 350 \\
Nuclear Fraction & 0.70 & 10.9 & 0.064 & 35 \\
Large Granules & 0.23 & 4.8 & 0.048 & 12 \\
Small Granules & 0.00 & 5.7 & 0.000 & 0 \\
Supernatant & 5.44 & 11.0 & 0.490 & 272 \\
\hline
\end{tabular}

The liver was homogenized in four volumes of $0.25 \mathrm{M}$ sucrose solution of $\mathrm{pH}$ 7.4. Each fraction was suspended in $0.25 \mathrm{M}$ sucrose of the same volume as the whole liver homogenate. The reaction mixture consists of $3.0 \mathrm{ml}$ of the each fraction mentioned above, $1.0 \mathrm{ml}$ of $0.1 \mathrm{M}$ phosphate buffer of $\mathrm{pH} 7.4,2.0 \mathrm{ml}$ of the boiled liver extract, and $2.0 \mathrm{ml}$ of $4 \times 10^{-4} \mathrm{M}$ pyridine-hemichromogen. The reaction was performed at $37^{\circ}$ for 20 minutes. Protein was measured by Kjeldahl's method.

Table II. Change in the activity of supernatant fraction under the addition of several other fractions

\begin{tabular}{|c|c|c|}
\hline Fraction & Additions & $\begin{array}{l}\text { Enzyme units } / 1.0 \mathrm{~g} \text { wet } \\
\text { weight of liver }\end{array}$ \\
\hline Supernatant & $0.25 \mathrm{M}$ sucrose of $\mathrm{pH} 7.4$ & 17.8 \\
\hline$\prime \prime$ & Nuclear Fraction & 18.7 \\
\hline$\prime \prime$ & Large Granules & 19.3 \\
\hline$\prime \prime$ & Small Granules & 17.8 \\
\hline
\end{tabular}

The reaction mixture consists of $3.0 \mathrm{ml}$ of the supernatant fraction, $2.0 \mathrm{ml}$ of the sucrose or of fractions given in the table, $1.0 \mathrm{ml}$ of $0.1 \mathrm{M}$ phosphate buffer, $\mathrm{pH} 7.4$ and $2.0 \mathrm{ml}$ of $4 \times 10^{-4} \mathrm{M}$ pyridine-hemichromogen.

centrifugation of the preincubated homogenate, standing at $2^{\circ}$ for 2 hours, increased in the activity by $60 \%$ in comparison with the supernatant from the homogente without preincubation (Table III). These facts were observed irrespective of the kind of homogenization medium, such as $0.1 \mathrm{M}$ phosphate buffer or $0.25 \mathrm{M}$ sucrose solution adjusted at $\mathrm{pH} 7.4$ with sodium carbonate (Table III). When the homogenate was previously centrifuged at $900 \mathrm{xg}$ for 15 minutes to remove the nuclear fraction, this phenomenon was completely disappeared. From these facts, it was assumed that the activation would occur mainly in the presence of the nuclear fraction. This assumption was further confirmed as follows; the supernatant preincubated with the nuclear and mitochondrial fractions which were separated each other prior to the incubation, increased in the activities by $46 \%$ and $16 \%$ by preincubation respectively. On the contrary, 
Table III. Change in the enzymatic activity of the supernatant after preincubation at $2^{\circ}$ for 2 hours

\begin{tabular}{|c|c|c|c|c|}
\hline Fraction preincubated & $\begin{array}{l}\text { Protein } \\
(\mathrm{mg} / \mathrm{ml})\end{array}$ & $\begin{array}{l}\text { Activity } \\
\text { (units/ml) }\end{array}$ & $\begin{array}{l}\text { Specific } \\
\text { activity } \\
\text { (units/mg } \\
\text { protein) }\end{array}$ & $\begin{array}{c}\text { Change in } \\
\text { specific } \\
\text { activity } \\
(\%)\end{array}$ \\
\hline $\begin{array}{l}\text { 13,000 xg, } 15 \mathrm{~min} . \\
\text { Supernatant }\end{array}$ & $\begin{array}{c}10.4 \\
(12.5)\end{array}$ & $\begin{array}{c}5.50 \\
(3.70)\end{array}$ & $\begin{array}{c}0.529 \\
(0.296)\end{array}$ & $\begin{array}{l}107^{*} \\
(103)^{* *}\end{array}$ \\
\hline $\begin{array}{l}900 \mathrm{xg}, 15 \mathrm{~min} . \\
\text { Supernatant }\end{array}$ & $\begin{array}{l}10.0 \\
(\longrightarrow)\end{array}$ & $\begin{array}{l}5.60 \\
(\longrightarrow)\end{array}$ & $\begin{array}{l}0.560 \\
(\longrightarrow)\end{array}$ & $\begin{array}{l}113 \\
(-)\end{array}$ \\
\hline Homogenate & $\begin{array}{c}10.2 \\
(12.5)\end{array}$ & $\begin{array}{c}8.15 \\
(5.45)\end{array}$ & $\begin{array}{c}0.799 \\
(0.436)\end{array}$ & $\begin{array}{c}161 \\
(152)\end{array}$ \\
\hline $\begin{array}{l}\text { Homogenate without } \\
\text { preincubation }\end{array}$ & $\begin{array}{c}10.0 \\
(12.5)\end{array}$ & $\begin{array}{c}4.95 \\
(3.60)\end{array}$ & $\begin{array}{c}0.495 \\
(0.288)\end{array}$ & $\begin{array}{c}100 \\
(100)\end{array}$ \\
\hline
\end{tabular}

After the centrifugation mentioned in the table, each fraction was stored at $2^{\circ}$. After 2 hours of the preincubation, the supernatant obtained by the centrifugation at $105,000 \mathrm{xg}$ for 60 minutes was assayed in the routine method.

$* 0.25 \mathrm{M}$ sucrose, $\mathrm{pH} 7.4$, as a homogenization medium.

** $0.1 \mathrm{M}$ phosphate buffer, $\mathrm{pH} 7.4$, as a homogenization medium.

Table IV. Change in the activity of the supernatant after preincubation with the nuclear or the large granule fraction

\begin{tabular}{|c|c|c|c|}
\hline \multirow[b]{2}{*}{$\begin{array}{c}\text { Fraction preincubated at } \\
0^{\circ} \text { for } 2 \text { hours }\end{array}$} & \multicolumn{2}{|c|}{ Activity } & \multirow{2}{*}{$\begin{array}{c}\text { Change } \\
\text { in the } \\
\text { activity } \\
\%\end{array}$} \\
\hline & $\begin{array}{c}\text { Before } \\
\text { preincubation } \\
\text { (units } / \mathrm{ml} \text { ) }\end{array}$ & $\underset{\begin{array}{c}\text { After } \\
\text { preincubation } \\
\text { (units/ml) }\end{array}}{ }$ & \\
\hline Supernatant & 4.05 & 3.80 & 94 \\
\hline Supernatant + Nuclear Fraction & 3.25 & 4.75 & 146 \\
\hline Supernatant+Large Granules & 3.10 & 3.60 & 116 \\
\hline Nuclear Fraction & 0.50 & 0.60 & \\
\hline Large Granules & 0.00 & 0.00 & \\
\hline
\end{tabular}

The mixture consists of $3.0 \mathrm{ml}$ of the supernantant, and $2.0 \mathrm{ml}$ of the nuclear or large granule fraction was preincubated at $2^{\circ}$ for 2 hours. After the preincubation, the mixture was centrifuged at $105,000 \mathrm{xg}$ for 60 minutes, and the supernatant obtained was assayed in the routine system.

supernatant, nuclear or mitochondrial fraction alone did not increase in the activity by preincubation (Table IV).

Upon dialysis for 2 hours against $0.1 \mathrm{M}$ phosphate buffer of $\mathrm{pH}$ 7.4, the activities of the activated and not activated supernatants were decreased to $26 \%$ and $33 \%$ of the original activities, respectively. And the decreased activities were recovered to $88 \%$ and $109 \%$ by the addition of boiled liver extract, respectively (Table V). These facts seemed to indicate that the activator released from the nuclear fraction was a low molecular substance and was loosely bound with the enzyme protein. 
Table V. The effect of dialysis and of boiled liver extract on the activity of activated and not activated supernatant

\begin{tabular}{c|c|c|c}
\hline \multicolumn{1}{c|}{ Fraction } & Before dialysis & \multicolumn{2}{|c}{ After dialysis } \\
\cline { 3 - 4 } (units/ml) & $\begin{array}{c}\text { No addition } \\
\text { (units/ml) }\end{array}$ & $\begin{array}{c}\text { +Boiled extract } \\
\text { (units/ml) }\end{array}$ \\
\hline Not activated supernatant & 3.90 & 1.30 & 4.25 \\
\hline Activated supernatant & 5.80 & 1.65 & 5.10 \\
\hline
\end{tabular}

The preparation obtained by the centrifugation at $105,000 \mathrm{xg}$ for 60 minutes immediately after the preparation of the liver homogenate was referred to as "not activated supernatant", and the supernatant obtained after the preincubation of the homogenate at $2^{\circ}$ for 2 hours was referred to as "activated one". The assay was performed in the routine system.

The activation was observed even in the case of the fasted animals whose activity was relatively low in contrast with the fed animals (Table VI). The relationship between the rate of activation and the decrease in the activity by starvation remains to be investigated.

Table VI. Effects of preincubation time and of diet on the activivy of the supernatant fraction

\begin{tabular}{c|c|c|c}
\hline $\begin{array}{c}\text { Exp. } \\
\text { no. }\end{array}$ & $\begin{array}{c}\text { Preincubation time } \\
\text { in minutes at } 2^{\circ}\end{array}$ & Diet & $\begin{array}{c}\text { Specific activity } \\
\text { (units/mg protein) }\end{array}$ \\
\hline 1 & 0 & + & 0.282 \\
2 & 0 & + & 0.363 \\
3 & 130 & + & 0.461 \\
4 & 140 & + & 0.423 \\
5 & 20 & - & 0.243 \\
6 & 30 & - & 0.112 \\
7 & 150 & - & 0.340 \\
8 & 180 & - & 0.395 \\
\hline
\end{tabular}

Diet + : fed on routine diet including vegetable and Okara, a product of soy bean.

Diet - : fasted for 16 hours.

The effect of temperature on the rate of activation of the supernatant by preincubation with the nuclear fraction is shown in Fig. 1. There are parallel relationship between the temperatures ranged $2^{\circ}$ to $37^{\circ}$ and the rate of activation within 30 minutes of preincubation.

The isolation and identification of this activator are now in progress.

Summary. 1) The activity of heme $\alpha$-methenyl oxygenase in the liver homogenate was found to be distributed in the supernatant 
fraction by Schneider's method of differential centrifugation.

2) The enzyme activity in the supernatant fraction increases upon preincubation with the nuclear fraction.

3) The activator released from the nuclear fraction seems to be a low molecular substance.

Acknowledgement. The author wishes to thank Prof. Y. Yamanura, Department of Biochemistry, Faculty of Medicine, Kyushu University, and Prof. K. Yamaoka, First Department of Internal Medicine, Faculty of Medicine, Kyushu University, and Dr. H. Nakajima, Department of Clinical Genetics, Tokyo Medical and Dental University, Tokyo, for their advices and encouragements during this work.

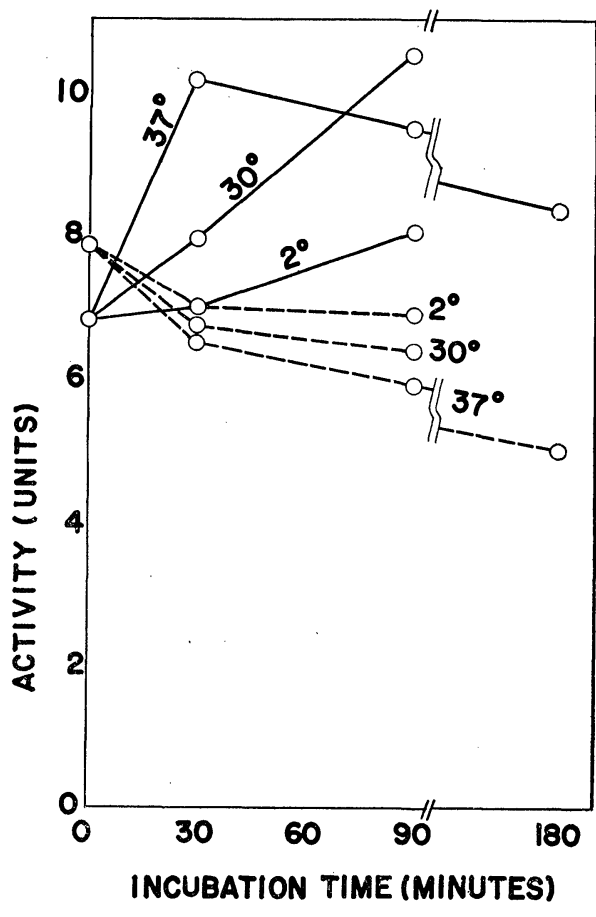

Fig. 1. Change in the activity of the supernatant fraction by preincubation with the nuclear fraction at different temperatures.

Supernatant Frantion + Nuclear Fraction.

Supernatant Fraction alone.

\section{References}

1) Nakajima, H.: Proc. Japan Acad., 34, 712 (1958).

2) Nakajima, H.: Proc. Japan Acad., 35, 144 (1959).

3) Nakajima, H., Takemura, T., Nakajima, O., and Yamaoka, K.: Proc. Japan Acad., 37, 497, 501, 579 (1961).

4) Yamaguchi, M., Nakajima, H., and Yamaoka, K.: Ibid., 37, 584 (1961).

5) Nakajima, H., Yamaoka, K.: Ibid., 37, 640 (1961).

6) Nakajima, H., Nakajima, O., and Yamaoka, K.: Ibid., 37, 643 (1961).

7) Nakajima, H.: in press.

8) Schneider, W. C.: J. Biol. Chem., 176, 259 (1948).

9) Takemura, T.: in press.

10) Warburg, O., and Christian, W.: Biochem. Z., 310, 384 (1941). 